\title{
Dealing with landscape fuzziness in user preference studies: Photo-based questionnaires in the Mediterranean context
}

\author{
Filipe Lucas Barroso ${ }^{\mathrm{a}, *}$, Teresa Pinto-Correia ${ }^{\mathrm{a}}$, Isabel L. Ramos ${ }^{\mathrm{b}}$, Diana Surováa ${ }^{\mathrm{a}}$, Helena Menezes ${ }^{\mathrm{a}}$

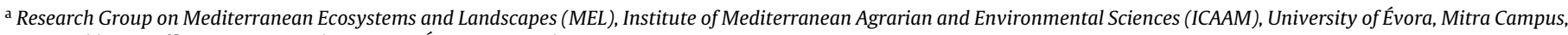 \\ Main Building - Offices 203, 204 and 205, 7000 Évora, Portugal \\ ${ }^{\mathrm{b}}$ CESUR - Center for Urban and Regional Systems, Technical University of Lisbon, Av. RoviscoPais, 1049 Lisbon, Portugal
}

\section{A R T I C L E I N F O}

\section{Article history:}

Received 16 February 2011

Received in revised form 27 August 2011

Accepted 11 November 2011

Available online 23 December 2011

\section{Keywords:}

Landscape preferences

Visualization tools

Photo manipulation

Mediterranean landscapes

Photo-based questionnaires

Landscape fuzziness

\begin{abstract}
A B S T R A C T
Mediterranean landscapes reveal extremely adequate conditions for the development of other functions besides production (nature conservation, recreation, life quality, local identity). These functions support the provision of public goods and services increasingly recognized by society. With this goal, the production of knowledge that may support decision is highly needed. In Mediterranean extensively used areas, the analysis of landscape features and related public preferences is complex, as the landscape pattern is highly fuzzy and land cover classes are often mixed. Resulting from multiple research developments, this paper demonstrates how photo-based surveys can be a suitable tool for assessing landscape preferences by specific public groups. Landscape functions addressed are closely linked to land cover patterns, as resulting from land cover systems. Thus using photographs in landscape questionnaires is useful in focusing the discussion on specific aspects, related with the variations in land cover and in their combinations with other specific landscape features. But the photos shown need to be clear and easily perceivable by the respondents. In order to cope with the underlying fuzziness of these landscapes, manipulation of images has been developed as the best solution so that the variations shown to respondents are adequately controlled in the study and landscape features are easily recognized by the respondents. The methodological approach as well as the results of applied approaches, of two studies on the users preferences, applied to a case-study area in Alentejo region, Portugal, are presented. The issues concerned with photo manipulation are a particular focus of discussion.
\end{abstract}

(C) 2011 Elsevier B.V. All rights reserved.

\section{Introduction}

Mediterranean landscapes are diverse and reflect a long history of human occupation, through complex and unique land use systems, adapted to a very heterogeneous environment (Grove \& Rackham, 2001; Pinto-Correia \& Vos, 2004). In the last decades, there has been a decline in the economic and social roles of agriculture and a decay of the very specific traditional land use systems, as well as an increased interest in new functions provided by these landscapes (de Groot, 2006; Hall et al., 2004; Sayadi and Calatrava, 2001; Sayadi, Gonzalez-Roa, \& Calatrava-Requena, 2009). From a space for production, Mediterranean rural landscapes are increasingly becoming spaces for consumption and conservation (de Lucio

\footnotetext{
* Corresponding author at: Grupo de Ecossistemas e PaisagensMediterrânicos, Instituto de CienciasAmbientais e Agrárias Mediterrânicas (ICAAM), Universidade de Évora - Polo da Mitra, Edificio Principal, Gabinete 204, 7000 Évora Portugal. Tel.: +351938252459.

E-mail addresses: filipelbarroso@gmail.com (F.L. Barroso), mtpc@uevora.pt (T. Pinto-Correia), isa.ramos@civil.ist.utl.pt (I.L. Ramos),dj@uevora.pt (D. Surová), hgm@uevora.pt (H. Menezes).
}

\& Múgica, 1994; Dearden, 1980; Hall et al., 2004; Holmes, 2006; Santos, 1998; Wilson \& Rigg, 2003; Wilson, 2007). The rural landscape is listed as one of the most relevant public goods provided by agriculture (Cooper, Hart, \& Baldock, 2009), creating new challenges to farming. Consequently, it is essential today to understand what the public is looking for in these rural landscapes in order to define guidelines for the management of these systems and for the targeting of the related policies (de Val, Atauri, \& de Lucio, 2006; Domon, 2011; Hart et al., 2011; Rogge, Nevens, \& Gulinck, 2007).

Mediterranean landscapes are marked by its fuzziness, related to the landscapes' physical structures, both horizontal and vertical. Many of the underlying concepts and tools for landscape ecological analysis (e.g., Botequilha Leitão, Miller, Ahern, \& McGarigal, 2006; Forman, 1995; Turner, Gardner, \& O’Neill, 2001) have been developed for landscapes with a more simple composition and clear boundaries between patches. There are still open challenges on how to address the complexity of Mediterranean landscapes, and how to describe and analyze them so that their fuzziness is taken into account (van Doorn \& Pinto-Correia, 2007). As relating landscape preferences to landscape structure is not a straight forward task in itself (Dramstad, Tveit, Fjellstad, \& Fry, 2006), its application 